\title{
Spatio-temporal variations in abundance and assemblage patterns of fish larvae and their relationships to environmental variables in Sirindhron Reservoir of the Lower Mekong Basin, Thailand
}

\author{
TUANTONG JUTAGATE ${ }^{1}$, ACHARA RATTANACHAI ${ }^{1}$, SURIYA UDDUANG ${ }^{2}$, \\ SITHAN LEK-ANG ${ }^{3}$ AND SOVAN LEK ${ }^{3}$ \\ ${ }^{1}$ Faculty of Agriculture, Ubon Ratchathani University, Warin Chamrab, Ubon Ratchathani, Thailand - 34190 \\ ${ }^{2}$ Faculty of Agriculture and Technology, Rajamangala University of Technology, Isan Surin Campus, Muang, \\ Surin, Thailand - 32000 \\ ${ }^{3} U M R 5174$ EDB, CNRS-University Paul Sabatier, 118 route de Narbonne -31062, Toulouse Cedex, France \\ e-mail: tuantong.j@ubu.ac.th
}

\begin{abstract}
The spatio-temporal dynamics of fish larvae in Sirindhron Reservoir, north-east Thailand, were investigated from February 2008 to January 2009. The five most abundant species accounted for $53.6 \%$ of the total catch and comprised Clupeicthys aesarnensis, Rasbora borapetensis, Barbonymus gonionotus, Esomus metallicus and Oreochromis niloticus. Total larval abundance and species richness varied among sampling months but did not vary with zones in the reservoir. The abundance and species richness of fish larvae showed correlation with flooding, vegetation cover, water level, water temperature and turbidity. A self-organising map (SOM) was used to represent the larval fish assemblage patterns and three assemblage patterns were clearly distinguished primarily according to seasons. In conclusion, the fish larval abundance was greatest during the wet season and the most diverse assemblages were found in the zones adjacent to the connected river upstream during the wet season.
\end{abstract}

Keywords: Fish larvae, Self-organising map, Spatio-temporal variations, Thailand

\section{Introduction}

Reservoirs are common aquatic habitats in Asia and the number of these has significantly increased in South-east Asia over the past 30 years, particularly in the Lower Mekong Basin (LMB) (Dugan et al., 2010). Twelve hydropower schemes have been proposed for the LMB in the mainstream i.e. from Laos to Vietnam, in addition to a number of damming projects on the tributaries, particularly in Laos and Cambodia (ICEM, 2010). Although a number of benefits and services are provided by reservoir damming, threats to the ecological integrity have been of much concern (Palaniswamy et al., 2015). Alteration of fish assemblages and loss of fish diversity are among the major impacts of river damming. A common alteration is the change from a fish community dominated by riverine species to one dominated by lacustrine species, which eventually leads to the local extirpation of many riverine fish species (Kruk and Penchack, 2003; Jutagate et al., 2012).

Although obligatory riverine fish species suffer severely from dam construction, facultative riverine species in contrast are generally regarded as well adapted to living in the reservoir along with lentic fishes (Kruk and Penchack,
2003). Information regarding limno-ecological aspects of a reservoir's resident species is necessary for fish stock assessment, management controls and administration of fishery resources on a sustainable basis (Chellappa et al., 2009; Debnath et al., 2015). There have been a number of works related to the reservoir fishes in LMB, most of which have focused on the spawning biology and size of parental stocks available in the reservoir. However, there have been only very few studies examining fish larvae, even though their life history and survival is critical for recruitment to the adult populations (Quist et al., 2004).

Early life stages are particularly vulnerable phase and during this period, fish larvae are subject to enormous mortality, which is sometimes over 90\% (Houde, 1994). Environmental factors, both abiotic and biotic, can affect the survival and abundance of fish larvae and thus they seek suitable habitats to maximise their survival (Humphries et al., 1999; Roseman et al., 2005). Abiotic factors have been found to be important, in which temperature is always of the most concern, because increase in environmental temperature results in increased metabolic rates, higher growth rates and lower mortality (Rankin and Sponaugle, 2011). Biotic factors include predation and competition for resources (both 
inter-specific and intra-specific) which play an important role in structuring the complexity of fish larval assemblages (Hindell et al., 2000). This implies that spatial distributions of fish larvae are not random (Prchalova et al., 2009).

Studies on the ecology of fish larvae in the LMB are in the early phases and mainly focus at the lotic system. To our knowledge, very few studies have been conducted in the lentic or reservoir systems within the Mekong Basin. The main objectives of the present study were to investigate the fluctuations in abundance and species richness, as well as to examine the assemblage structures of fish larvae in Sirindhron Reservoir in LMB, the results of which could help environmental managers to reconcile the benefits of impoundment, such as fisheries, with protection of the local aquatic ecology and aid in the overall river basin management planning process (Iacone Santos et al., 2013).

\section{Materials and methods}

Study area

The study was conducted in Sirindhorn Reservoir, the fifth biggest reservoir in Thailand, located in Ubon Rathchathani Province (Fig. 1) in the north-eastern region. The reservoir was created in 1971 by damming the Lam Dom Noi River for hydroelectric purposes, which covers an area of 28,800 ha and has relatively shallow depth of about $5 \mathrm{~m}$ (Jutagate et al., 2003). Fortyseven fish species have been recorded from the reservoir (Dumrongtripob and Janesirisak, 1996).

\section{Sampling procedures}

Sampling was conducted monthly, from February 2008 to January 2009, in five zones, from the upstream end of the reservoir to just above the dam site. Sampling was conducted on the day of full-moon in each month to avoid the influence of a lift net fishery where in lights used by fishermen during the new moon phase (Jutagate et al., 2003). Sampling was carried out in the littoral zone, as it is known to be the habitat preferred by larval fish (Brosse et al., 2007; Ríha et al., 2011). Maximum and mean depths of sampling sites were 1.07 and $0.48 \mathrm{~m}$, respectively. The bottom type was a mixture of sand and mud, covered by flooded vegetation.

A total of 10 sampling sites (Fig. 1) were selected on the left and right littoral areas of each zone. Electro-sampling could not be conducted because of the low conductivity (average $25 \mu \mathrm{S} . \mathrm{cm}^{-1}$ ) in this reservoir and poisoning was prohibited. Therefore, sampling was conducted in each site by establishing a meshed plot $\left(5 \times 5 \mathrm{~m}^{2}, 5 \mathrm{~mm}\right.$ stretched mesh), with a plot height of $1.5 \mathrm{~m}$. Each plot was set about $1 \mathrm{~m}$ from the bank in the morning of the sampling date. For the 10 nets, setting time varied between 05.30 to $08.30 \mathrm{hrs}$. As soon as two plots were set up in each zone, one research staff along with one local fisher dragged a very fine mesh (160 mesh $\mathrm{cm}^{-2}$ ) drag net for about $20 \mathrm{~min}$. in each plot. Bigger fishes were released back and larval fish were preserved in $4 \%$ formaldehyde. The larval samples were brought back to the laboratory, identified to species level following Termvidchakorn and Hortle (2013) and

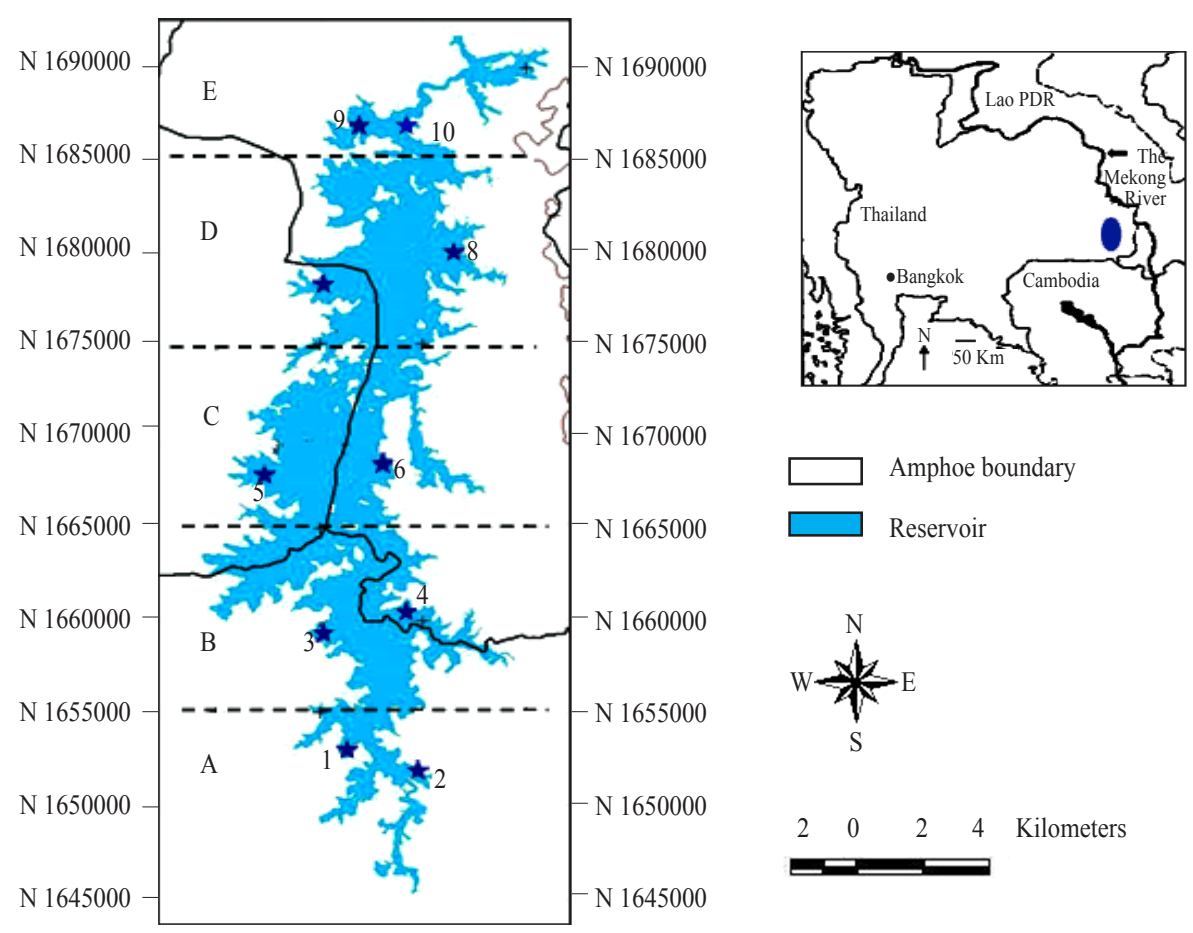

Fig. 1. Map showing and map of Sirindhorn Reservoir (0) as well as sampling zones and sites ( $\star$ ) 
enumerated. Water level of each sampling site was measured to the nearest $0.1 \mathrm{~m}$. Environmental parameters viz., water temperature $\left({ }^{\circ} \mathrm{C}\right)$, dissolved oxygen (DO; $\mathrm{mg} \mathrm{l}^{-1}$ ) and turbidity (NTU), in the sampling sites were measured in situ using a YSI 556-MPS multi-probe system. Percentage of flooded vegetation cover was visually estimated as the percentage of bottom area covered (class interval $=5 \%$ ).

\section{Data analyses}

Data on fish larvae from each survey was summarised as total abundance and species richness. In terms of abundance, the results were also presented as percentages of relative abundance $(\% \mathrm{RA})$ and occurrence frequency $(\% \mathrm{OF})$, where:

$\% \mathrm{RA}=$ (Number of individuals of each larval species/Total number of individuals) $\mathrm{x} 100$.

$\% \mathrm{OF}=($ Number of samples that had each larval species/Total number of samples) x100.

To investigate spatio-temporal patterns of both parameters, we used repeated-measures analysis of variance (RM ANOVA). Abundance data was $\log _{10}(x+1)$ transformed prior to analysis to improve normality. The Tukey HSD test was applied when the ANOVA revealed significant difference.

To investigate the associations between larval abundance $\left[\log _{10}(x+1)\right.$ transformed] and species richness to each environmental variable, the non-parametric regression, 'Locally weighted scatter plot smoother' or 'Lowess' (Cleveland, 1979) was applied. In this procedure, each co-ordinate is smoothed using a defined proportion of the neighbours nearest to the target point, over parts of their ranges (Brosse and Lek, 2002). Optimal fitting is obtained iteratively by minimising the residuals between the observed and estimated values.

The patterns in the larval assemblage were investigated using an unsupervised artificial neural network (ANN), a self-organising map (SOM, Kohonen, 2001). The matrix of species abundance data $\left[\log _{10}(x+1)\right.$ transformed] was used. Prior to analyses, rare species (those with fewer than 20 larvae in total samples) were excluded and the result was a data matrix of 120 samples x 37 species, i.e. numbers of fish larvae captured for each species as columns and numbers at each survey time as rows. The architecture of the SOM consisted of two layers of neurons, first, the input layer, which was composed of 37 neurons (i.e. fish species), connected to each vector of the data set and second, the two-dimensional output layer, which was composed of 56 neurons laid out on a hexagonal lattice. Number of neurons in the output layer (C) was computed according to the formula $\mathrm{C}=5 \sqrt{\mathrm{n}}$, where ' $\mathrm{n}$ ' is the number of samples (Kalteh et al., 2008).

The SOM algorithm calculates the connection intensities (i.e. vector weights) between input and output layers using an unsupervised competitive learning procedure (Kohonen, 2001), which iteratively classifies samples in each neuron according to their similarity in species composition. Thus, the SOM preserves the neighborhood so that samples with close species abundances were grouped together on the map, whereas samples with very different species abundances were far from each other (Kohonen, 2001; Kalteh et al., 2008). The quality of the SOM map was measured by two criteria, i.e. quantisation and topographical errors, which measures the map resolution and topology preservation (Kohonen, 2001). The non-parametric permutational multivariate analysis of variances (PERMANOVA; Anderson, 2001) was used to identify significant differences among clusters, based on occurrence probability $(\% \mathrm{OP})$ of individual fish species of each cluster. The $\% \mathrm{OP}$ was approximated by the connection intensity of the SOM and estimated during its learning procedure (Kohonen, 2001). Prior to analysis the \%OP data were fourth root transformed. The $\% \mathrm{OP}$ of individual species was also used to explain the characteristic of each assemblage, where $>50 \%, 50-25 \%$ and $<25 \%$ were considered as dominant, common and rare, respectively (Schifino et al., 2004). The ANN-SOM was computed and analysed under the Matlab environment (The Mathworks, Inc., Natick, MA, USA) by using the ANN software package (http://www.cis. hut.fi). Other statistical analyses were conducted under the Program R-Statistics (R Development Core Team, 2012).

\section{Results}

\section{Abundance and species richness}

Fortysix larval fish species from 16 families, totaling 10,681 individuals (Table 1), were collected throughout the study. The five most abundant species accounted for 53.6\% of the total catch. Clupeidae - Clupeicthys aesarnensis (19.0\%) dominated the total catch, followed by Cyprinidae - Rasbora borapetensis (10.6\%), Barbonymus gonionotus (10.2\%), Esomus metallicus $(9.6 \%)$ and Cichlidae Oreochromis niloticus (4.2\%). Larvae of these species were found year round, except for B. gonionotus and O. niloticus, which were absent in February 2008 and January 2009, respectively. C. aesarnensis and $R$. borapetensis were recorded in every sample, i.e. occurrence frequency (\% OF) was $100 \%$. There were 11 other species that had a $\% \mathrm{OF}$ of more than $50 \%$ (Table 1). Peak larval abundance $(146 \pm 40)$ and species richness $(25 \pm 4)$ occurred in July (Fig. 2a, b), but patterns associated with zone were less clear (Fig. 2c, d). However, the most abundant $(97 \pm 59)$ and the highest species richness $(18 \pm 9)$ were observed in the furthest upstream area, i.e. Zone A.

The transformed abundance data showed normality (Shapiro's normality test, $\mathrm{p}>0.05$ ). Repeated measures ANOVA revealed highly significant differences in both abundance and species richness $(p<0.001)$ among the sampling months, but not among sampling zones. Tukey HSD test revealed that there were generally two different groups (Table 2) for both abundance and species richness 
Table 1. List of fish larvae collected in Sirindhorn Reservoir between February 2008 and January 2009

\begin{tabular}{|c|c|c|c|c|c|}
\hline Family & Scientific name & Habitats & Abbreviation & $\%$ RA & $\% \mathrm{OF}$ \\
\hline Ambassidae & Parambassis siamensis & Lentic & Pasi & 3.7 & 60.0 \\
\hline Anabantidae & Anabas testudineus & Lentic & Ante & 1.3 & 50.8 \\
\hline Bagridae & Hemibagrus filamentus & Lentic & Hefi & 0.6 & 22.5 \\
\hline Belonidae & Xenentodon canciloides & Lentic & Xeca & 0.9 & 39.2 \\
\hline Osphronemidae & Trichopsis vittata & Lentic & Trvi & 2.7 & 90.8 \\
\hline Osphronemidae & Trichopsis schalleri & Lentic & Trsc & 2.5 & 93.3 \\
\hline Osphronemidae & Trichopodus trichopterus & Lentic & Trtr & 0.5 & 24.2 \\
\hline Channidae & Channa striata & Lentic & Chst & 1.6 & 39.2 \\
\hline Cichlidae & Oreochromis niloticus & Lentic & Orni & 4.2 & 77.5 \\
\hline Clariidae & Clarias batrachus & Lentic & Clba & 0.1 & 8.3 \\
\hline Clupeidae & Clupeichthys aesarnensis & Lotic & Clae & 19.0 & 100 \\
\hline Cobitidae & Lepidocephalichthys hasselti & Lotic & Leha & 0.1 & 2.5 \\
\hline Cyprinidae & Rasbora borapetensis & Lotic & Rabo & 10.6 & 100.0 \\
\hline Cyprinidae & Barbonymus gonionotus & Lotic & Bago & 10.2 & 70.8 \\
\hline Cyprinidae & Esomus metallicus & Lotic & Esme & 9.6 & 74.2 \\
\hline Cyprinidae & Rasbora dusonensis & Lotic & Radu & 3.8 & 70.0 \\
\hline Cyprinidae & Barbonymus altus & Lotic & Baal & 3.1 & 30.0 \\
\hline Cyprinidae & Hampala dispar & Lotic & Hadi & 2.9 & 76.7 \\
\hline Cyprinidae & Henicorhynchus siamensis & Lotic & Hesi & 2.7 & 33.3 \\
\hline Cyprinidae & Rasbora trilineata & Lotic & Ratr & 1.8 & 38.3 \\
\hline Cyprinidae & Barbodes aurotaeniatus & Lotic & Baau & 1.8 & 51.7 \\
\hline Cyprinidae & Puntius brevis & Lotic & Babr & 1.5 & 46.7 \\
\hline Cyprinidae & Barbonymus schwanenfeldii & Lotic & Basc & 1.4 & 25.0 \\
\hline Cyprinidae & Systomus rubripinnis & Lotic & Syru & 1.2 & 33.3 \\
\hline Cyprinidae & Cyclocheilichthys armatus & Lotic & Cyar & 1.2 & 25.0 \\
\hline Cyprinidae & Amblypharyngodon chulabhornae & Lotic & Amch & 1.0 & 35.0 \\
\hline Cyprinidae & Osteochilus vittatus & Lotic & Osvi & 1.0 & 41.7 \\
\hline Cyprinidae & Hampala macrolepidota & Lotic & Hama & 0.9 & 18.3 \\
\hline Cyprinidae & Cyclocheilichthys apogon & Lotic & Cyap & 0.7 & 6.7 \\
\hline Cyprinidae & Osteochilus lini & Lotic & Osli & 0.7 & 18.3 \\
\hline Cyprinidae & Labeo chrysophekadion & Lotic & Lach & 0.5 & 25.0 \\
\hline Cyprinidae & Mystacoleucus atridorsalis & Lotic & Myar & 0.5 & 17.5 \\
\hline Cyprinidae & Discherodontus ashmeadi & Lotic & Dias & 0.4 & 17.5 \\
\hline Cyprinidae & Rasbosoma spilocerca & Lotic & Rasp & 0.1 & 2.5 \\
\hline Cyprinidae & Rasbora septentrionalis & Lotic & Rase & $<0.1$ & 2.5 \\
\hline Cyprinidae & Rasbora beauforti & Lotic & Rabe & $<0.1$ & 3.3 \\
\hline Cyprinidae & Rasbora sumatrana & Lotic & Rasu & $<0.1$ & 0.8 \\
\hline Eleotridae & Oxyeleotris marmorata & Lentic & Oxma & 0.7 & 28.3 \\
\hline Mastacembelidae & Macrognathus semiocellatus & Lentic & Mase & 0.3 & 15.8 \\
\hline Mastacembelidae & Macrognathus siamensis & Lentic & Masi & 0.1 & 10.0 \\
\hline Mastacembelidae & Mastacembelus favus & Lentic & Mafa & 0.1 & 7.5 \\
\hline Pristolepididae & Pristolepis fasciata & Lentic & Prfa & 2.3 & 61.7 \\
\hline Nandidae & Nandus oxyrhynchus & Lentic & Naox & $<0.1$ & 2.5 \\
\hline Notopteridae & Notopterus notopterus & Lotic & Nono & 0.9 & 33.3 \\
\hline Siluridae & Ompok bimaculatus & Lotic & Ombi & 0.6 & 32.5 \\
\hline Siluridae & Ompok siluroides & Lotic & Omsi & 0.3 & 16.7 \\
\hline
\end{tabular}

Abb: Abbreviation, \%RA: Percentages of relative abundance, $\% \mathrm{OF}$ : Occurrence frequency

between the dry (i.e. November to March) and wet (i.e. May to September) seasons. For the transition months, abundance and species richness in October were not statistically different to those in the wet season. Meanwhile, species richness of fish larvae in April was similar to that of the dry season, but the abundance tended to be similar to that of the wet season.
Variations in environmental variables and their relationships to abundance and species richness of fish larvae

For the whole reservoir, two peaks of rainfall were observed during the study period with the first peak in May $(422.8 \mathrm{~mm})$ and the second peak between August and October $(454.7 \mathrm{~mm})$. Inflow to the reservoir was highest in 


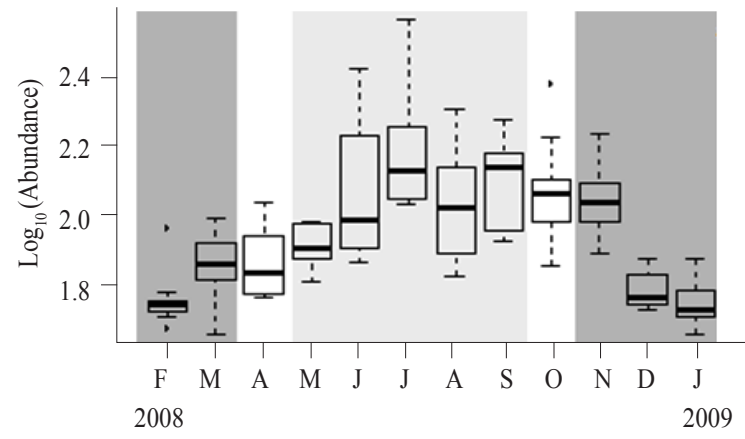

(a)

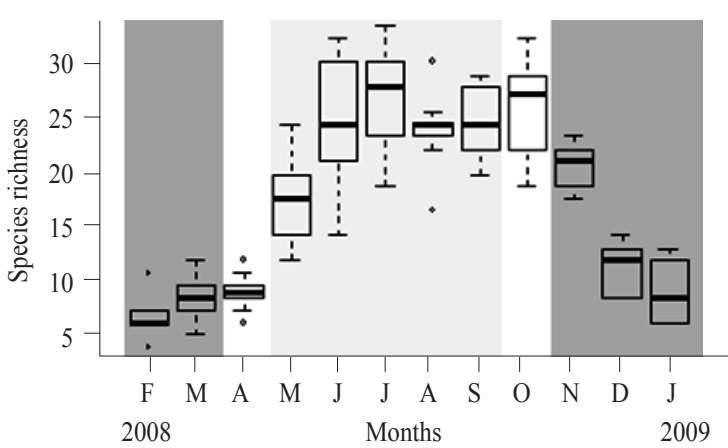

(c)

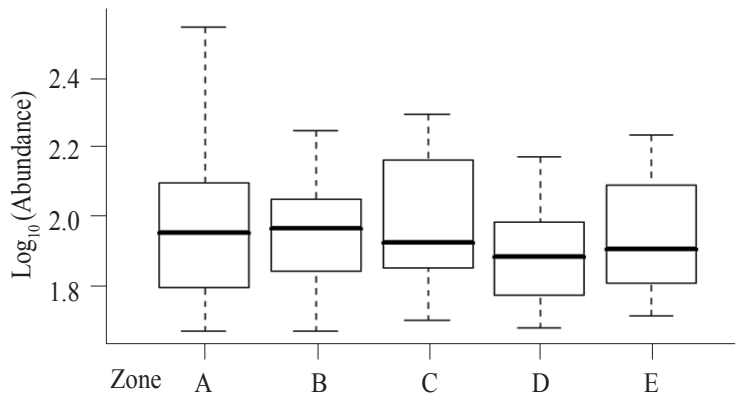

(b)

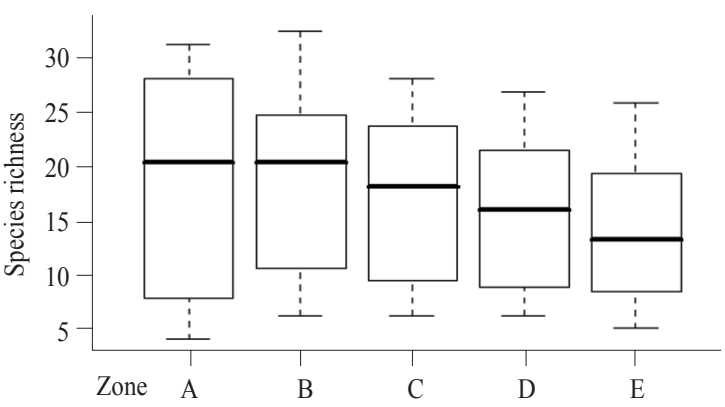

(d)

Fig. 2. Temporal and spatial variations in abundance and species richness of the fish larvae collected in Sirindhorn Reservoir between February 2008 and January 2009. The light and dark shades in 2a and c, indicate the periods of wet season and dry season, respectively

Table 2. Results of Tukey HSD comparisons $(\alpha=0.05)$ for temporal differences in abundance (upper) and species richness (lower) of fish larvae collected in Sirindhorn Reservoir between February 2008 and January 2009

\begin{tabular}{|c|c|c|c|c|c|c|c|c|c|c|c|c|c|}
\hline Abundance & Feb & Mar & Apr & May & Jun & Jul & Aug & Sep & Oct & Nov & Dec & Jan & Abundance \\
\hline Feb & & NS & NS & NS & $*$ & $*$ & $*$ & $*$ & $*$ & $*$ & NS & NS & Feb \\
\hline Mar & NS & & NS & NS & $*$ & $*$ & $*$ & $*$ & $*$ & $*$ & NS & NS & Mar \\
\hline Apr & NS & NS & 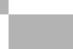 & NS & $*$ & $*$ & NS & $*$ & $*$ & NS & NS & NS & Apr \\
\hline May & $*$ & $*$ & $*$ & t & NS & $*$ & NS & $*$ & NS & NS & NS & NS & May \\
\hline Jun & $*$ & $*$ & $*$ & * & 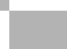 & NS & NS & NS & NS & NS & $*$ & $*$ & Jun \\
\hline Jul & $*$ & $*$ & $*$ & $*$ & NS & & NS & NS & NS & NS & $*$ & $*$ & Jul \\
\hline Aug & $*$ & $*$ & $*$ & $*$ & NS & NS & & NS & NS & NS & $*$ & $*$ & Aug \\
\hline Sep & $*$ & $*$ & $*$ & $*$ & NS & NS & NS & & NS & NS & $*$ & $*$ & Sep \\
\hline Oct & $*$ & * & $*$ & $*$ & NS & NS & NS & NS & & NS & $*$ & $*$ & Oct \\
\hline Nov & $*$ & * & $*$ & NS & NS & * & NS & NS & $*$ & & $*$ & $*$ & Nov \\
\hline Dec & NS & NS & NS & $*$ & $*$ & * & $*$ & $*$ & $*$ & $*$ & & NS & Dec \\
\hline Jan & NS & NS & NS & $*$ & $*$ & * & $*$ & $*$ & $*$ & $*$ & NS & & Jan \\
\hline Species richness & Feb & Mar & Apr & May & Jun & Jul & Aug & Sep & Oct & Nov & Dec & Jan & Species richness \\
\hline
\end{tabular}

* = Significantly different at $\alpha=0.05 ; \mathrm{NS}=$ Non-significant at $\alpha=0.05$

August (451 million cubic meters, MCM). The peak in water storage was in October (1,692.9 MCM), and the lowest level was in July (Fig. 3).

For each zone, temporal fluctuation of water depth generally conformed to the fluctuations of rainfall and inflow (Fig. 4a). There was no clear pattern in the distribution of vegetation among the littoral zones or through time (Fig. 4b). Water temperature was above $22^{\circ} \mathrm{C}$ for the entire year, and was above $29^{\circ} \mathrm{C}$ for most of the wet season (Fig. 4c).
Concentrations of DO ranged between approximately 4.0 and $9.0 \mathrm{mg} \mathrm{l}^{-1}$, and declined during the wet season in all zones, except for zone E (Fig. 4d). The turbidity (Fig. 4e) increased after the onset of the wet season, remaining high for a few months before dropping in October.

The scatter plots of each environmental variable $v s$ larval abundance and species richness illustrated the heterogeneity of the data set. Except for dissolved oxygen (within the range 4 to $9 \mathrm{mg} \mathrm{l}^{-1}$ ), all other environmental variables 


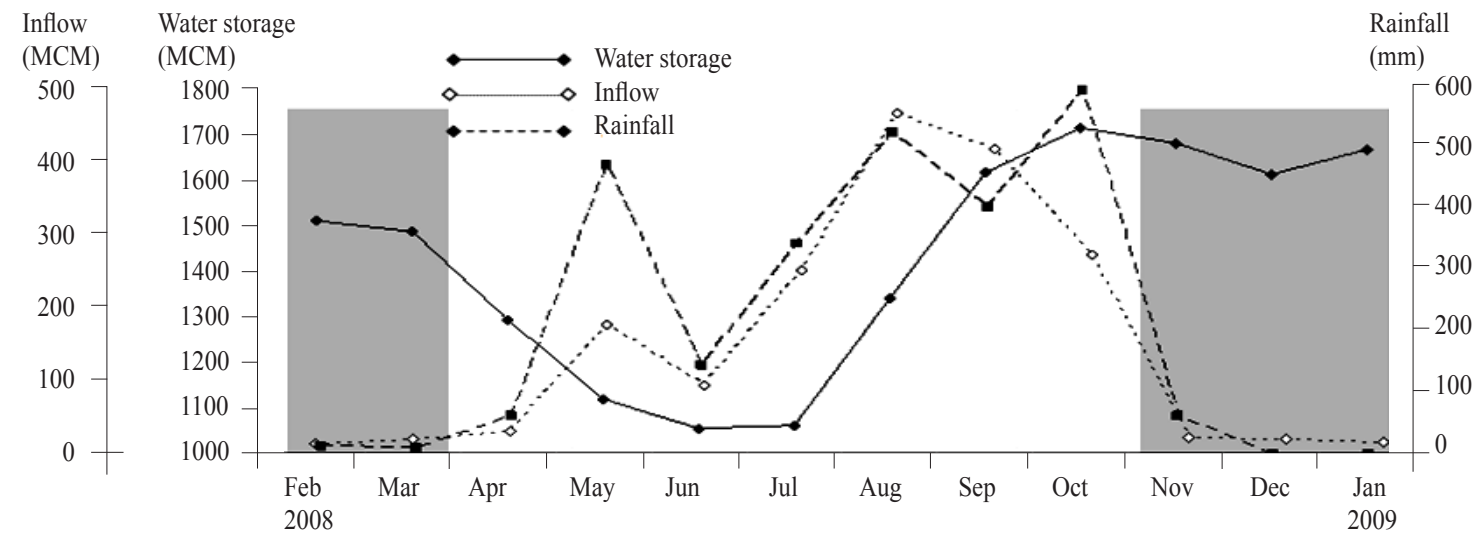

Fig. 3. Fluctuations in rainfall, inflow and water storage in Sirindhorn Reservoir between February 2008 and January 2009. The light and dark shades indicate periods of wet season and dry season, respectively

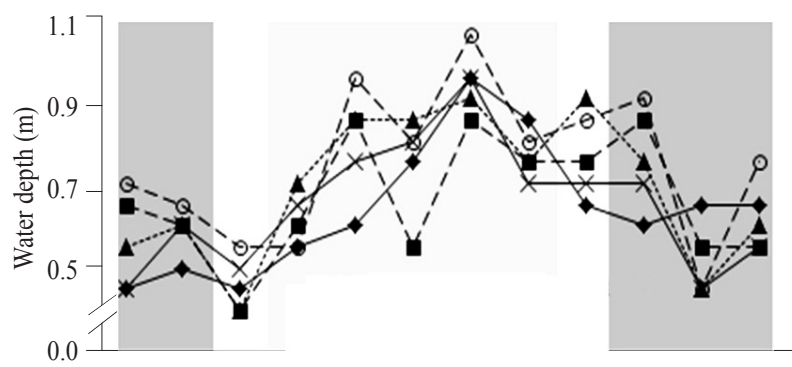

(a)

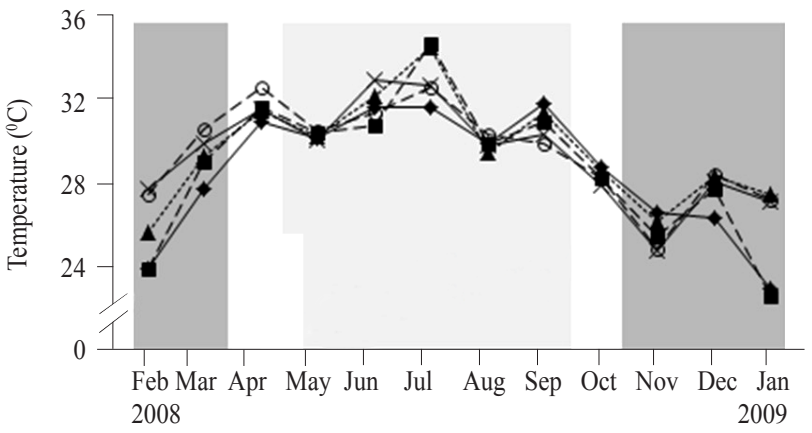

(c)

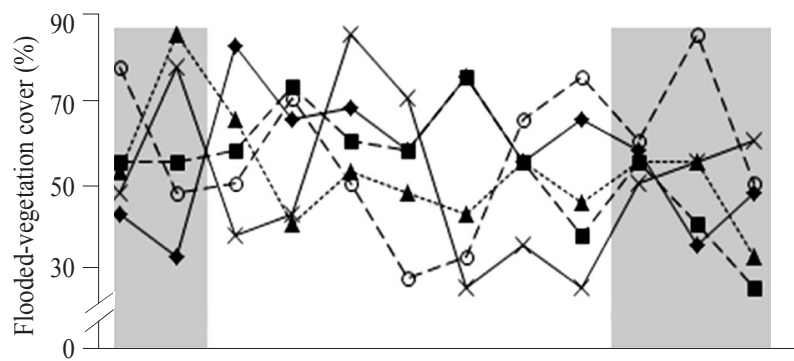

(b)

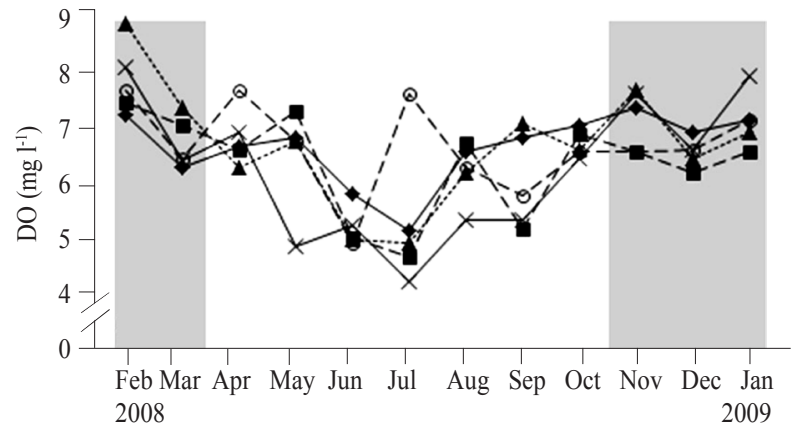

(d)

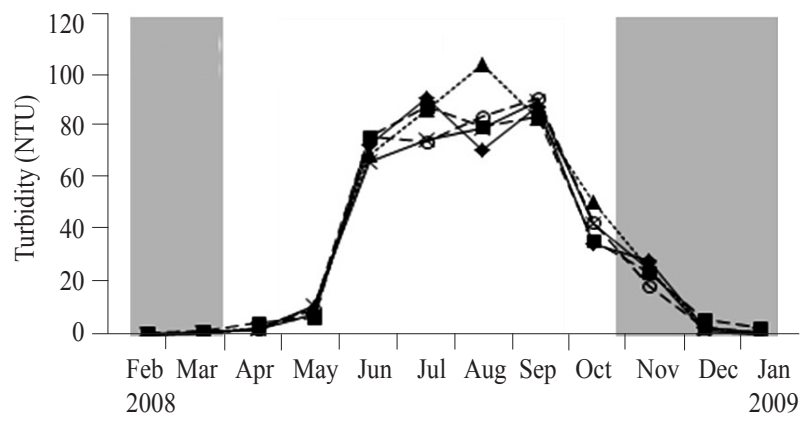

(e)

$\multimap \mathrm{A},-\oplus-\cdot \mathrm{B}, \cdots \bullet \cdots \mathrm{C}, \longrightarrow \mathrm{D},-\oplus-\cdot \mathrm{E}$

Fig. 4. Fluctuations of selected environmental variables (mean values) in different zones (A to E) of Sirindhorn Reservoir between February 2008 and January 2009. Light and dark shades indicate the periods of wet season and dry season, respectively. 
produced large variations in the Lowess curves, implying they were associated with both abundance and species richness. Abundance and species richness tend to increase from the shallow water (i.e., about $0.3 \mathrm{~m}$ ) to about $0.6 \mathrm{~m}$, after which it plateaued (Fig. 5a, 6a). For the percentage of flooded vegetation cover (Fig. 5b, 6b), the Lowess fitting was a unimodal curve, indicating that the larval abundance and species richness were maximal for medium values of about $40-60 \%$ flooded vegetation. Dissolved oxygen in the range 4 to $9 \mathrm{mg} \mathrm{l}^{-1}$ and the Lowess curve varied slightly (Fig. 5c). However, species richness tended to decline at the higher values of DO (Fig. 6c). Temperature (Fig. 5d, 6d), and turbidity (Fig. 5e, 6e) revealed similar patterns, i.e., increasing larval abundance and species richness, within the ranges of the environmental data obtained.

\section{Patterns of larval fish assemblages}

The SOM map showed low final quantisation (0.374) and topographical errors (0.010), which made the map authentic. The SOM revealed three clusters i.e., assemblage patterns (Fig. 7a, b) and the characteristics of each cluster were significantly different (PERMANOVA, $p=0.014$ ). It is apparent that the larval fish assemblages were different by seasons (Fig. 3c). Except for the samples from zone A and $\mathrm{B}$, the assemblages in Clusters I and II were during the wet season (i.e. May to September) and transition period from wet to dry seasons, i.e. October. The main difference between Cluster I and II was that $80 \%$ of the sampling in Cluster I was within the upper to middle parts of the reservoir (i.e. Zones A - C), whereas $73 \%$ of samplings in Cluster II were from the lower part (i.e. Zones D, E). Cluster III, therefore, was dedicated to the assemblage patterns during the dry season (i.e. November to March) as well as the transition period from dry to wet seasons, i.e. April.

Clusters were characterised by the probability of occurrence $(\% \mathrm{OP})$ of each species on the cluster level (Fig. 8). The larval fishes of C. aesarnensis dominated (\%OP $>50 \%$ ) every assemblage. The assemblage pattern of other commonly found species ( $\% \mathrm{OP}>25 \%)$ of Cluster I included facultative riverine fish species such as $B$. gonionotus, Barbodes aurotaeniatus, Osteochilus vittatus, Puntius brevis, Henicorhynchus siamensis, Barbonymus altus, Systomus rubripinnis and Labeo chrysophekadion. The larvae of some lentic species were commonly found in this assemblage such as Anabas testudineus, O. niloticus, Trichopsis schalleri and

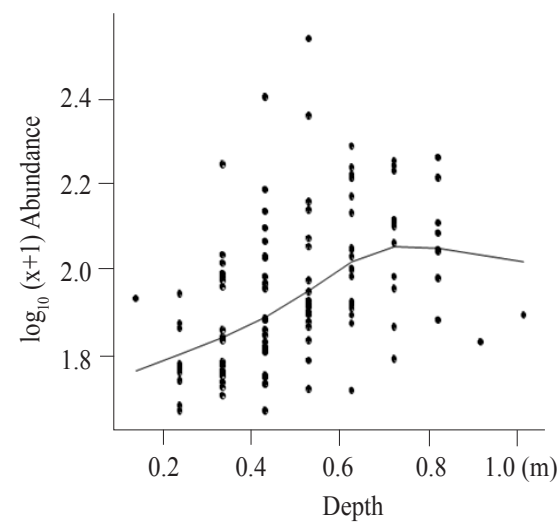

(a)

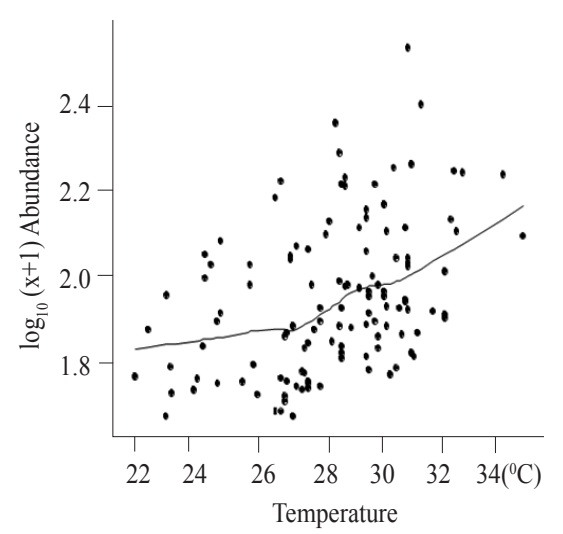

(d)

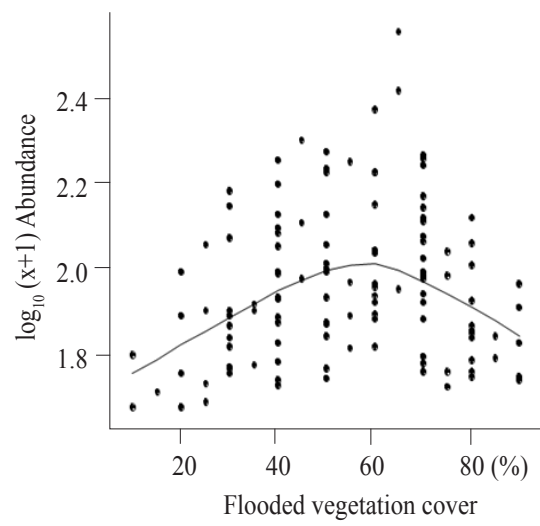

(b)

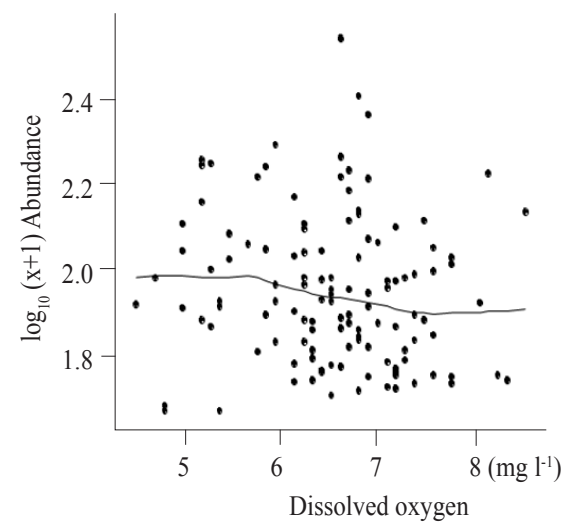

(c)

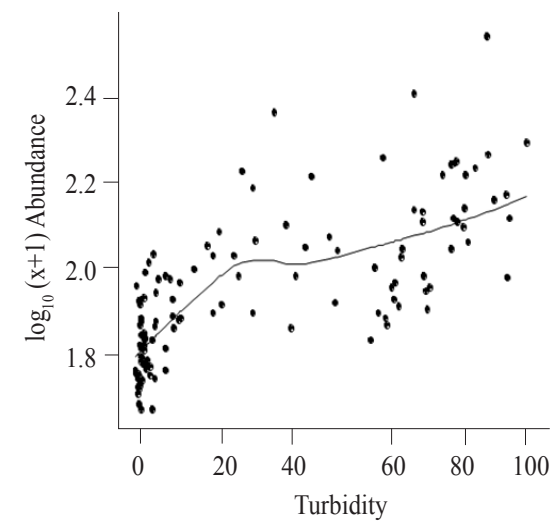

(e)

Fig. 5. Bivariate plots of the five environmental variables against fish larval abundance in Sirindhorn Reservoir. The Lowess curves (solid lines) were used to fit the data 


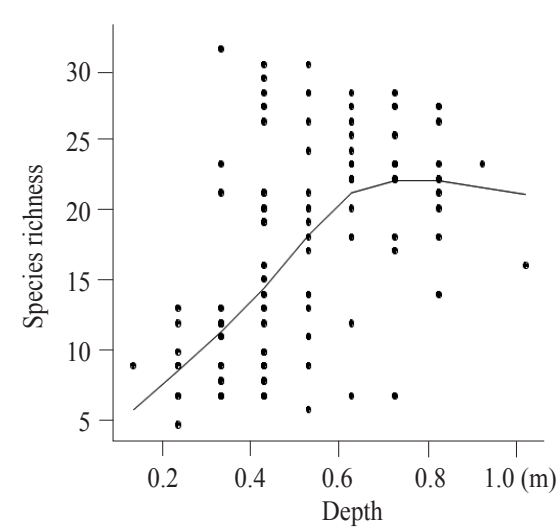

(a)

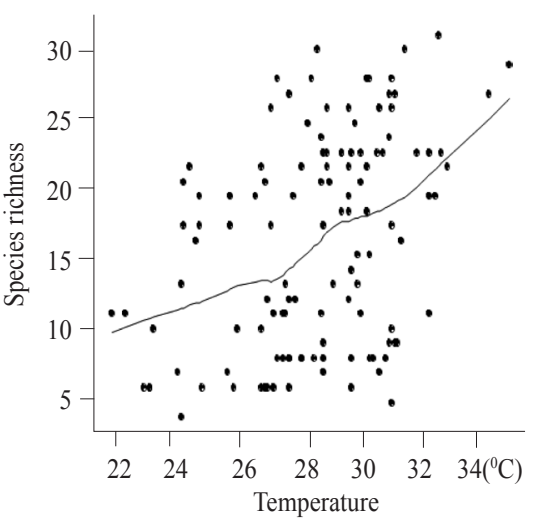

(d)

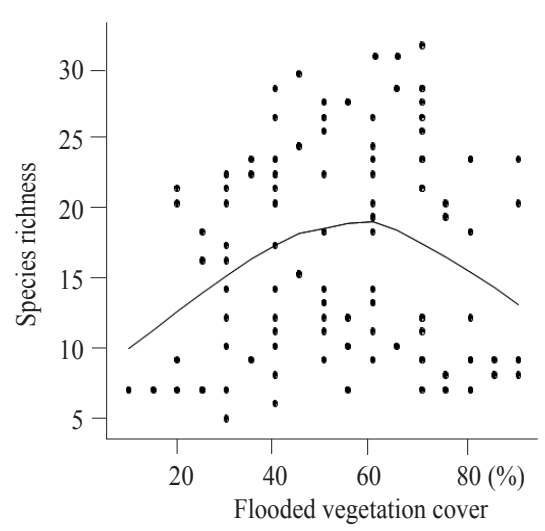

(b)

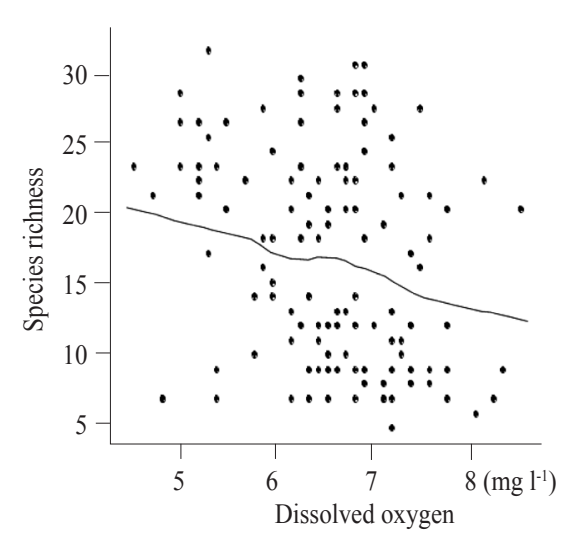

(c)

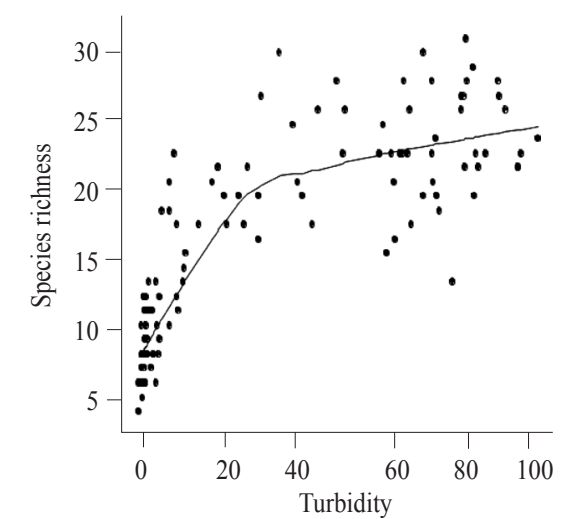

(e)

Fig. 6. Bivariate plots of the six environmental variables against species richness of fish larvae in Sirindhorn Reservoir. The Lowess curves (solid lines) were used to fit the data

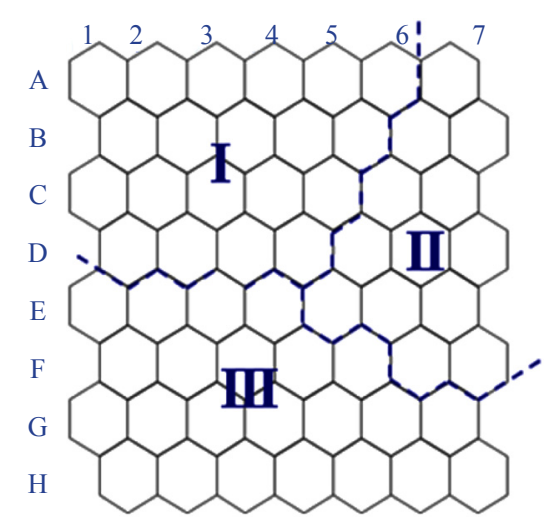

(a)
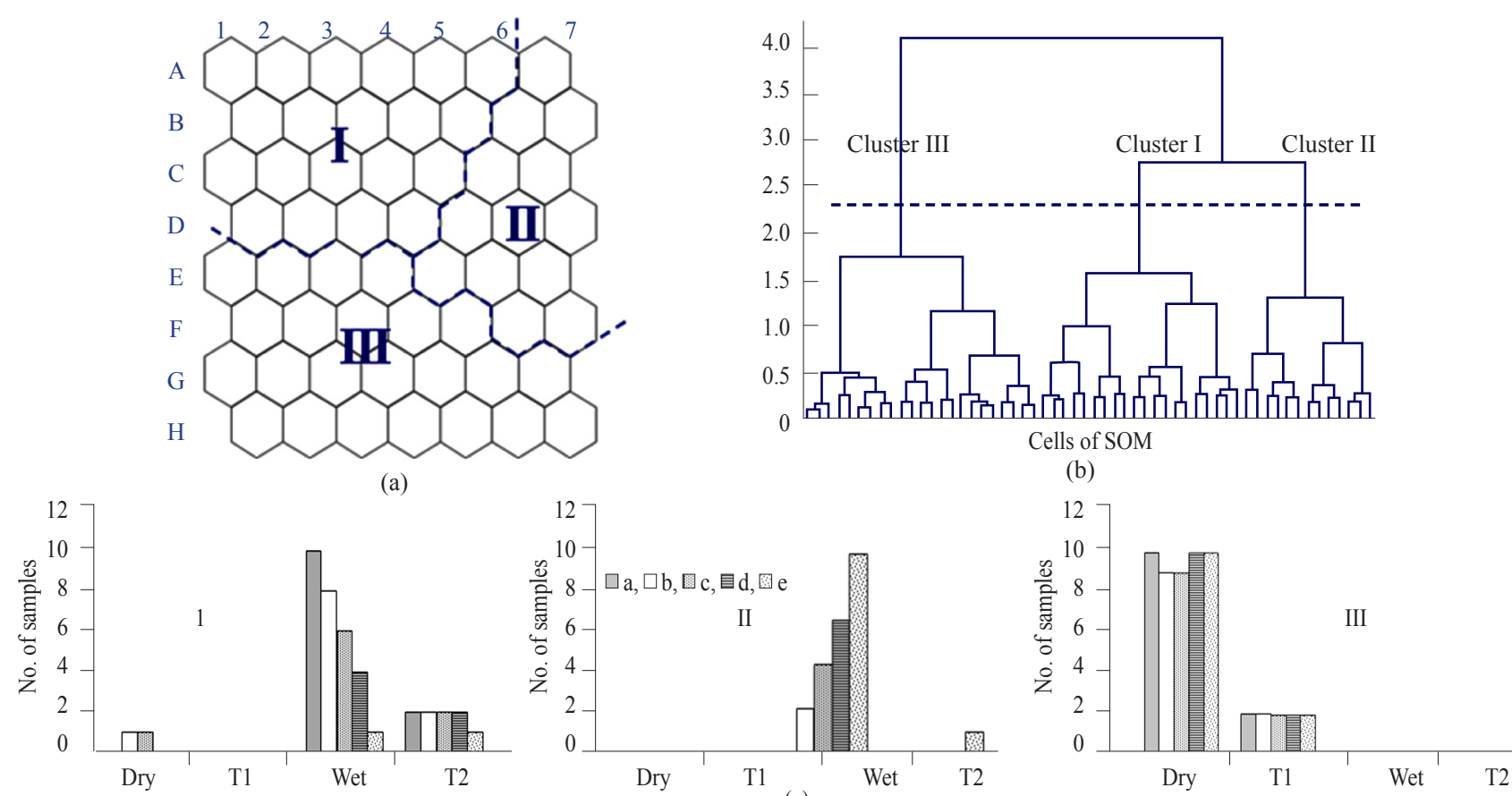

Fig. 7. a: Clustering pattern of larval fish assemblages on the self-organising map (SOM), b: Clusters identified by the Ward's Euclidean method are indicated by dashed lines, c: Bar plots showing the number of samples in each season of the three clusters. T1 and T2 are the transition periods from dry to wet seasons and wet to dry seasons, respectively 

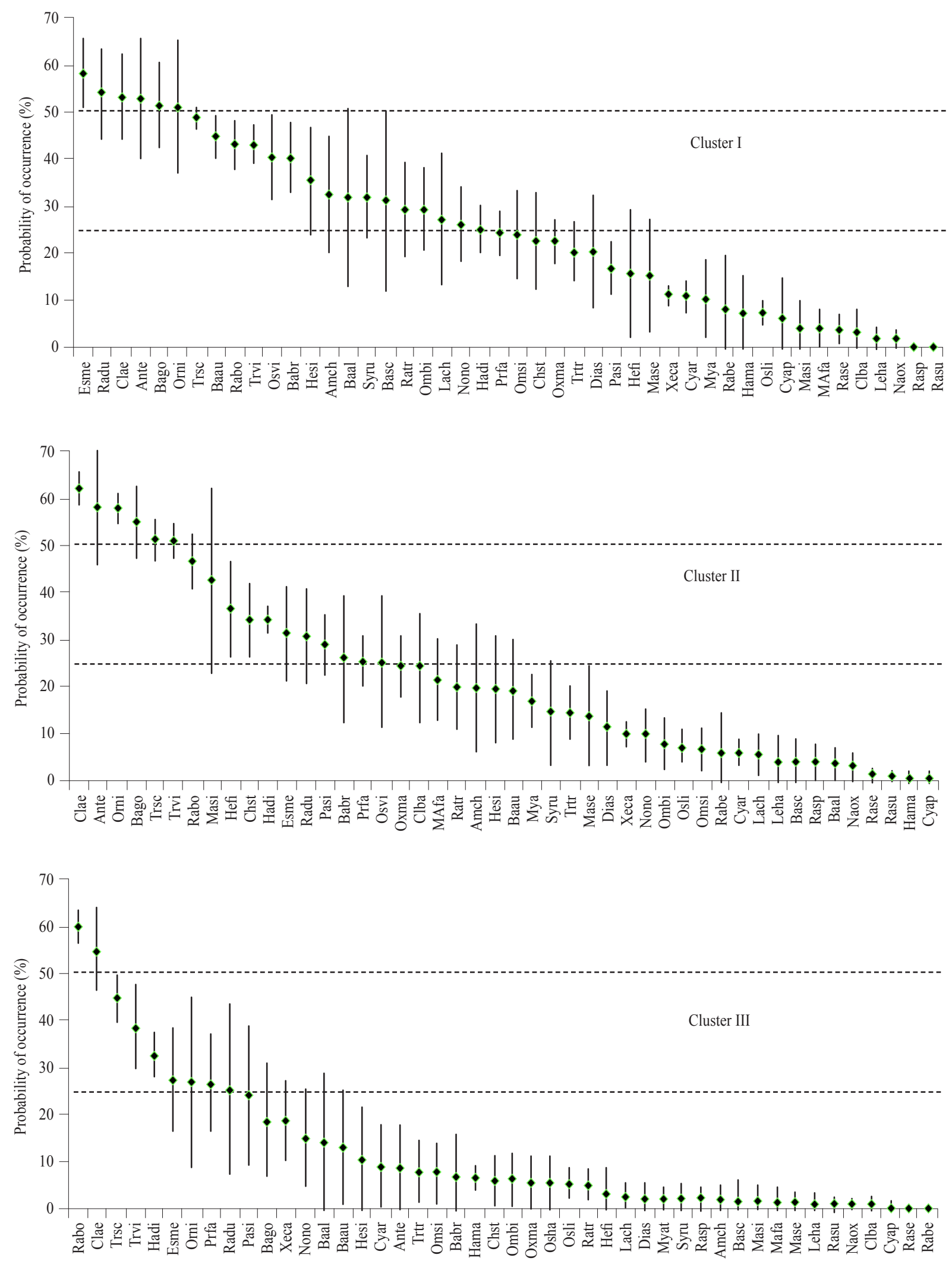

Fig. 8. Graphs showing the average $(\downarrow)$ and standard deviation of the occurrence probability $(\% \mathrm{OP})$ of fish larvae (for full names see Table 1) in each assemblage (\%OP was obtained from the connection intensity of the SOM) 
Trichopsis vittata. The larvae of these lentic species were also common in the assemblage pattern of Cluster II. The other common larval fishes, in this assemblage included lentic species such as Macrognathus siamensis, Channa striata, Parambassis siamensis, Pristolepis fasciata, Oxyeleotris marmorata, Clarias batrachus and Mastacembelus favus. The assemblage pattern of Cluster III was dominated by only two species, namely $R$. borapetensis and $C$. aesarnensis. The common species were T. schalleri, T. vittata, Hampala dispar, E. metallicus, O. niloticus, P. fasciata and Rasbora dusonensis, while $\%$ OP of the other larval species were less than $25 \%$.

\section{Discussion}

The structure and dynamics of larval fish assemblages have the potential to provide insights into the recruitment (McKenna et al., 2008) that maintains the fish diversity, in aquatic ecosystems. This study examined larval fish abundance and richness in relation to environmental variables and their assemblage patterns in the Sirindhron Reservoir, Thailand. The littoral area is always dominated by larval fish and represented the fish species in the ecosystem (Grenouillet and Pont, 2001; Brosse and Lek, 2002). Of the 47 species of fish known to inhabit this reservoir (Dumrongtripob and Janesirisak, 1996), all but one species, the swamp eel(Monopterus javanensis), were collected during this study. The overwhelming capture of fish larvae in fine mesh drag net is not unexpected. This gear is recommended to collect the fish larvae because it is effective for larval and juvenile fishes both in limnetic and littoral areas (Claramunt et al., 2005; Fryda et al., 2008).

Larval abundance is, in part, a product of spawning effort, which is related to the abundance of broodstock adults (Chambers and Trippel, 1997). The most abundant larval species, $C$. aesarnensis, is the species that gives greatest yield, i.e. about $60 \%$ of the annual total catch in the Sirindhorn Reservoir (Jutagate et al., 2003; 2012). This small clupeid thrives in many reservoirs in the LMB, although it seems not to be as abundant in rivers (Valbo-Jorgensen et al., 2009). The larvae of cyprinid fishes were next most abundant and this is not surprising given that cyprinids are by far the most diverse family in the tropics. In South-east Asia, cyprinids generally contribute to $40 \%$ or more, of the species in the watershed (Beamish et al., 2006) and many are considered to be facultative riverine species, especially the small cyprinids (Welcome et al., 2006), such as Rasbora spp. and Esomus spp. Another abundant species was tilapia, O. niloticus, which has been introduced from tropical Africa to many other tropical countries and has established successful populations in reservoir environments (De Silva et al., 2004).

Temporal trends in larval fish abundance and species richness in the Sirindhorn Reservoir were marked, and mirrored the known reproductive season of the fishes. Three adults of the five most abundant species are known to spawn all year round, i.e. C. aesarnensis, R. borapetensis and E. metallicus (Termvidchakorn and Hortle, 2013). Most species spawned during the wet season, in a similar fashion to most Mekong species (Valbo-Jorgensen et al., 2009).

The abundance and richness displayed a uni-modal relationship with flooded vegetation cover. Aquatic vegetation provides a structural refuge for larvae, protecting them from predation and can also provide protection for zooplankton, which is an important source of food for larval fish (Grown et al., 2003; Ye et al., 2006). However, the foraging efficiency of larval or adult fish is reduced in habitats with very high complexity and intermediate vegetation coverage often represents the best compromise between food availability and foraging efficiency, explaining the uni-modal relationship (Grenouillet and Pont, 2001; Brosse and Lek, 2002). The increased depth implies extensive flooding of terrestrial vegetation and could relate to production of prey resources for larvae (Quist et al., 2004). However, the plateau shape of relationships between water level and species richness as well as abundance indicated that the larval fish preferred the shallow littoral area rather than the deeper zone (Brosse et al., 2007).

Species richness and abundance were positively associated with temperature. Temperature is considered to be one of the strongest factors structuring larval fish assemblages. This is because temperature affects physiological rates, including respiratory and feeding rates and possibly the growth efficiency of the larvae (Baumgartner et al., 2008; McKenna et al., 2008). Daga et al. (2009) reported that the temperature yielding the highest abundance of fish larvae in the tropics was around $30^{\circ} \mathrm{C}$ which was also found true for Sirindhorn Reservoir, where water temperatures were above $29^{\circ} \mathrm{C}$ for the majority of the wet season. There was little difference in DO among areas and months similar to the other relatively shallow lakes (Cheng et al., 2010) and there were no obvious Lowess trends with larval abundance. Besides, DO ranged between 4 and $9 \mathrm{mg} \mathrm{l}^{-1}$ in this study and was beyond $50 \%$ of oxygen saturation, which is suitable for zooplankton (Guevara et al., 2009) and should be also suitable for ichthyoplankton, i.e., fish larvae, as well. Turbid conditions may be an indication of suspended sediment or abundant food for the more pelagic groups as well as fish larvae (McKenna et al., 2008). The increase in turbidity, therefore, would benefit the fish larvae if not beyond the threshold level, which would limit both abundance and species richness of larval fish. A strong negative correlation between fish larval density and low water clarity, e.g. limited numbers, reduced consumption and growth and decreased condition, has been reported (Roseman et al., 2005; DeBoer et al., 2016). This could explain a plateau pattern of 
relationships between turbidity and fish larval abundance as well as species richness, as observed in this study.

The larval assemblage structure was primarily grouped by seasonal effects (i.e. dry vs. wet seasons). Assemblage of Cluster I occurred in the upper section of the reservoir during the wet season and showed high $\% \mathrm{OP}$ of the facultative riverine species such as cyprinids and catfishes. The adults of these fishes require continuous water runoff in the inlet to trigger their spawning in that area (Chellappa et al., 2009; Daga et al., 2009; Suvarnaraksha et al., 2011). They spawn during wet season and their larvae then, drift to the connected flooded littoral area for their development (Humphries et al., 1999; Roseman et al., 2005).

Assemblage structure of Cluster II, i.e. assemblage in the lower part during the wet season, showed high \%OP of lentic species larvae. Most of tropical lentic fish are opportunistic breeders and may have an extended spawning season, but peak spawning activity is normally during the wet season (Valbo-Jorgensen et al., 2009). Adults of these fish are relatively sedentary and exhibit limited distribution, mostly in the littoral zone and in the floodplain during flood season to lay their eggs and rear the larvae (Valbo-Jorgensen et al., 2009). Thus, manipulating the optimal timing, duration and magnitude of the flooding regime by dam is important to this assemblage (Jurajda et al., 2004). The least diverse assemblage was Cluster III, i.e. assemblage pattern during the dry season. In this assemblage, all three dominant species and five out of seven common species were the small sized species. The life history trait of these fishes is opportunistic, which allows them to adapt and establish in various environments (Winemiller, 1989).

Very few studies have been concerned on maintaining integrity of fish biodiversity in the LMB reservoirs. Almost of these studies were carried out on adult fishes and studies are too limited for the fish larvae. Conservation measures to maintain the diversity and abundance of fish larvae have to be drawn from the understanding of the spatial and temporal variations in fish larval assemblage as well as their preference environment (Gogola et al., 2013). This study has revealed that the abundance and species richness of fish larvae in a LMB reservoir were associated to the environmental condition of the habitat. Larval abundance and species richness was greatest during the wet season, and the most diverse assemblage pattern was found in the zones adjacent to the connected river upstream during the wet season, i.e. when peak inflow into the reservoir was taking place. The highly productive environment that characterises this area at this time, is likely to benefit the broodstock of many fish species and their larvae, which occupy the nearby littoral area. The study also revealed that within the littoral area, larval abundance and species richness was greatest in the areas with intermediate vegetation coverage. Management actions that control access to fisheries in the upstream sections of reservoirs during the wet season and control of vegetation coverage will aid the prosperity of the fish larvae of the reservoir.

\section{Acknowledgements}

The authors wish to thank the editor and anonymous reviewer who provided constructive comments on the manuscript. This work was financially supported by the National Research Council of Thailand to Ubon Ratchathani University.

\section{References}

Baumgartner, G., Nakatani, K., Gomes, L. C., Bialetzki, A., Sanches, P. V. and Makrakis M. C. 2008. Fish larvae from the upper Parana River: Do abiotic factors affect larval density? Neotrop. Ichthyol., 6: 551-558.

Beamish, F. W. H., Sa-ardrit, P. and Tongnunui, S. 2006. Habitat characteristics of the cyprinidae in small rivers in Central Thailand. Environ. Biol. Fish.,76: 237-253.

Brosse, S., Grossman, G. D. and Lek, S. 2007. Fish assemblage patterns in the littoral zone of a European reservoir. Freshwater Biol., 52: 448-458.

Brosse, S. and Lek, S. 2002. Relationships between environmental characteristics and the density of age-0 Eurasian perch Perca fluviatilis in the littoral zone of a lake: a non-linear approach. Transact. Am. Fish. Soc., 131: 1033-1043.

Chambers, R. C. and Trippel, E. A. 1997. Early life history and recruitment in fish populations. Chapman and Hall, London, $593 \mathrm{pp}$.

Chellappa, S., Bueno, R. M. X., Chellappa, T., Chellappa, N. T. and Almeida-e-Val, V. M. F. 2009. Reproductive seasonality of the fish fauna and limno-ecology of semi-arid Brazilian reservoirs. Limnologica, 39: 325-329.

Cheng, L., Lek, S., Loot, G., Lek-Ang, S. and Li, Z. 2010. Variations of fish composition and diversity related to environmental variables in shallow lakes in the Yangtze River basin. Aquat. Living Resour., 23: 417-426.

Claramunt, R. M., Shoup, D. E. and Wahl, D. H. 2005. Comparison of pushnets and tow nets for sampling larval fish with implications for assessing littoral habitat utilisation. North Am. J. Fish. Manage., 25: 86-92.

Cleveland, W. S. 1979. Robust locally - weighted regression and scatter plot smoothing. J. Am. Stat. Ass., 74: 829-836.

Daga, V. S., Gogola, T. M., Sanches, P. V., Baumgartner, G., Baumgartner, D., Piana, P. A., Gubiani, E. A. and Delariva, R. L. 2009. Fish larvae assemblages in two floodplain lakes with different degrees of connection to the Parana River, Brazil. Neotrop. Ichthyol., 7: 429-438.

De Silva, S. S., Subasinghe, R. P., Bartley, D. M. and Lowther, A. 2004. Tilapias as alien aquatics in Asia and the pacific: a review. FAO Fish. Tech. Pap., No. 453. FAO, Rome, 65 pp. 
Debnath, B., Krishnan, M., Ananthan P. S., Sharma, A. and Sharma, R. 2015. Fisheries of Gumti (Dumboor) Reservoir in Tripura: production, performance and management. Indian J. Fish., 62: $14-20$

De Boer, J. A., Webber, C. M., Dixon, T. A. and Pope K. L. 2016. The influence of a severe reservoir drawdown on springtime zooplankton and larval fish assemblages in Red Willow Reservoir, Nebraska. J. Freswater Ecol., 31: 131-146.

Dugan, P. J., Barlow, C., Agostinho, A. A., Baran, E., Cada, G. F., Chen, D., Cowx, I. G., Ferguson, J. W., Jutagate, T., Mallen-Cooper, M., Marmulla, G., Nestler, J., Petrere, M., Welcomme, R. L. and Winemiller, K. O. 2010. Fish migration, dams, and loss of ecosystem services in the Mekong Basin. Ambio., 39: 344-348.

Dumrongtripob, J. and Janesirisak, S. 1996. Hydrobiological and fishery resources survey in Sirindhorn Reservoir in 1993. Ubon Ratchathani Fisheries Development Center, Ubon Ratchathani. 86 pp. (in Thai with English abstract).

Fryda, N. J., Koupal, K. D. and Hoback, W. W. 2008. Assessment of larval crappie (Pomoxis spp.) abundance and lengths in day and night push net collections from coves. J. Freshwater Ecol., 23: 529-535.

Grenouillet, G. and Pont, D. 2001. Juvenile fishes in macrophyte beds: influence of food resources, habitat structure and body size. J. Fish Biol., 59: 939-959.

Gogola, T. M., Sanches, P. V., Gubiani, E. A. and da Silva, P. R. 2013. Spatial and temporal variations in fish larvae assemblages of Ilha Grande National park, Brazil. Ecol. Freshwater Fish., 22: $95-105$

Grown, I., Gehrke, P. C., Astles, K. L. and Pollard, D. A. 2003. A comparison of fish assemblages associated with different riparian vegetation types in the Hawkesbury-Nepean River system. Fish. Manage. Ecol., 10: 209-220.

Guevara, G., Lozano, P., Reinoso, G. and Villa, F. 2009. Horizontal and seasonal patterns of tropical zooplankton from the eutrophic Prado Reservoir (Colombia). Limnologica, 39: 28-39.

Hindell, J. S., Jenkins, G. P. and Keough, M. J. 2000. Evaluating the impact of predation by fish on the assemblage structure of fishes associated with seagrass (Heterozostera tasmanica) (Martens ex Ascherson) den Hartog and unvegetated sand habitats. J. Exp. Mar. Biol. Ecol., 255: 153-174.

Houde, E. D. 1994. Differences between marine and freshwater fish larvae: implications for recruitment. ICES J. Mar. Sci., 51: 91-97.

Humphries, P., Kinga, A. J. and Koehn, J. D. 1999. Fish, flows and flood plains: links between freshwater fishes and their environment in the Murray-Darling River system, Australia. Environ. Biol. Fish., 56: 129-151.

Iacone-Santos, A. B., Albieri, R. J. and Araujo, F. G. 2013. Seasonal response of fish assemblages to habitat fragmentation caused by an impoundment in a Neotropical river. Environ. Biol. Fish., 96: 1377-1387.
ICEM 2010. The MRC strategic environmental assessment of hydropower on the Mekong mainstream. International Center for Environmental Management, Hanoi. 23 pp.

Jurajda, P., Ondrackova, M. and Reichard, M. 2004. Managed flooding as a tool for supporting natural fish production in the man made lentic water bodies. Fish. Manag. Ecol., 11: 237-242.

Jutagate, T., De Silva, S. S. and Mattson, N. S. 2003. Yield, growth and mortality rate of the Thai river sprat (Clupeichthys aesarnensis Wongratana, 1983) in Sirinthorn Reservoir, Thailand. Fish. Manage. Ecol., 10: 221-231.

Jutagate, T., Srichareondham, B., Lek, S., Amaraasinghe, U. S. and De Silva, S. S. 2012. Variations, trends and patterns in fish yields of large reservoirs in Thailand. Lake Reserv. Res. Manage., 17: 35-53.

Kalteh, A. M., Hjorth, P. and Berndtsson, R. 2008. Review of the self-organising map (SOM) approach in water resources: analysis, modelling and application. Environ. Modell. Softw., 23: 835-845.

Kohonen, T. 2001. Self-organizing maps, $3^{\text {rd }}$ edn., Springer, Berlin, $501 \mathrm{pp}$.

Kruk, A. and Penczak, T. 2003. Impoundment impact on populations of facultative riverine fish. Ann. Limnol. Int. J. Limnol., 39: $197-210$.

McKenna, J. E., Davis, B. M., Fabrizio, M. C., Savino, J. F., Todd, T. N. and Bur, M. 2008. Ichthyoplankton assemblages of coastal west-central Lake Erie and associated habitat characteristics. J. Great Lakes Res., 34: 755-769.

Palaniswamy, R., Manoharan, S. and Mohan A. 2015. Characterisation of tropical reservoirs in Tamil Nadu, India in terms of plankton assemblage using multivariate analysis Indian J. Fish., 62: 1-13.

Prchalova, M., Kubecka, J., Cech, M., Frouzova, J., Draštík, V., Hohausova, E., Juza, T., Kratochvil, M., Matena, J., Peterka, J., Riha, M., Tuser, M. and Vasek, M. 2009. The effect of depth, distance from dam and habitat on spatial distribution of fish in an artificial reservoir. Ecol. Freshwater Fish. 18: $247-260$.

Quist, M. C., Pember, K. R., Guy, C. S. and Stephen, J. L. 2004 Variation in larval fish communities: implications for management and sampling designs in reservoir systems. Fish. Manage. Ecol., 11: 107-116.

R Development Core Team 2012. R: A language and environment for statistical computing. R Foundation for Statistical Computing, Vienna. http://www.r-project.org

Rankin, T. L. and Sponaugle, S. 2011. Temperature influences selective mortality during the early life stages of a coral reef fish. PLoS One, 6: 1-9 (e16814).

Riha, M., Kubeeka, J., Prchalova, M., Mrkvicka, T., Cech, M., Drastik, V., Frouzova, J., Hohausova, E., Juza, T., Kratochvíl, M., Peterka, J., Tušer, M. and Vašek, M. 2011. The influence of diel period on fish assemblage in the unstructured littoral of reservoirs. Fish. Manage. Ecol., 18: 339-347. 
Roseman, E. F., Taylor, W. W., Hayes D. B., Tyson, J. T. and Haas, R. C. 2005. Spatial patterns emphasize the importance of coastal zones as nursery areas for larval walleye in western Lake Erie. J. Great Lakes Res., 31: 28-44.

Schifino, L. C., Fialho, C. B. and Verani, J. 2004. Fish community composition, seasonality and abundance in Fortaleza Lagoon, Cidreira. Braz. Arch. Biol. Technol., 47: 755-763.

Suvarnaraksha, A., Lek, S., Lek-Ang, S. and Jutagate, T. 2011. The life history of the riverine cyprinid Henicorhynchus siamensis (Sauvage, 1881) in a small reservoir. J. Appl. Ichthyol., 27: 995-1000.

Termvidchakorn, A. and Hortle, K. G. 2013. A guide to larvae and juveniles of some common fish species from the Mekong River Basin. Mekong River Commission, Phnom Penh, 234 pp.
Valbo-Jorgensen, J., Coates, D. and Hortle, K. G. 2009. Fish diversity in the Mekong River Basin. In: Campbell, I. C. (Ed.), The Mekong: biophysical environment of an international river basin, Elsevier, Amsterdam, p. 161-196.

Winemiller, K. O. 1989. Patterns of variation in life history among South American fishes in seasonal environments. Oecologia, 81: 225-241.

Ye, S., Zhongjie, L., Lek-Ang, S., Feng, G., Lek, S. and Cao, W. 2006. Community structure of small fishes in a shallow macrophytic lake (Niushan Lake) along the middle reach of the Yangtze River, China. Aquat. Living Resour., 19: 349-359. 